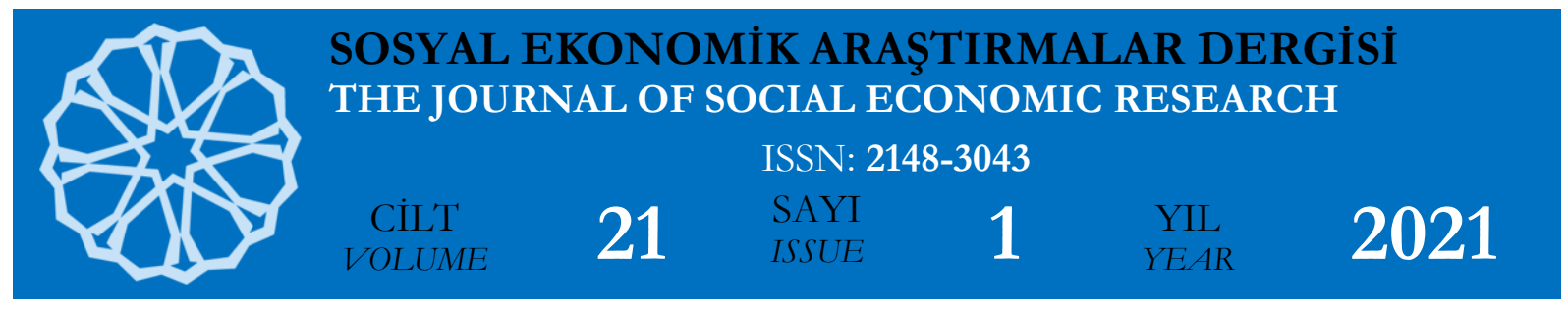

\title{
ANALYSIS OF THE RELATIONSHIP BETWEEN NOTIFICATIONS OF FOOTBALL CLUBS AND STOCK RETURNS USING EVENT STUDY METHOD
}

\section{FUTBOL KULÜPLERININ BILLDIRIMLERİ ILE HISSSE SENETLERI ARASINDAKİ ILLISKININ ETKINLIIK CALIŞMASI YÖNTEMİ KULLANILARAK ANALIZZI}

Mesut DOĞANa, Mustafa KEVSER ${ }^{b}$, Sevgi SÜMERLİ SARIGÜLc

aAssociate Prof., Afyon Kocatepe Üniversity, Department of Accounting and Tax Applications, Afyonkarahisar, Turkey. ORCID: 0000-0001-68791361

E-posta:

mesutdogan07@gmail.com

bAssistant Prof., Bandırma Onyedi Eylül University, Department of Banking and Insurance, Balıkesir, Turkey. ORCID: 0000-0003-05861662

E-posta:

mkevser@bandirma.edu.tr

cAssistant Prof., Kayseri

University, Department of

Marketing and International

Trade, Kayseri, Turkey.

ORCID: 0000-0002-3820-

6288

E-posta:

ssumerli@kayseri.edu.tr

Sorumlu Yazar:

Mustafa Kevser

Makale Türü

Araştırma Makalesi

Makale Geliş Tarihi

03.03.2021

Makale Kabul Tarihi 29.04.2021

\section{ABSTRACT}

Purpose - The purpose of this study is to examine the effect of the Public Disclosure Platform (PDP) notifications of Beşiktaş, Galatasaray, Fenerbahçe and Trabzonspor clubs on stock returns.

Methodology -In the research, the data of 2009-2010/2019-2020 seasons were used and the changes in stock returns on (date) and afterwards were determined. However, due to the COVID-19 outbreak, the data included in 2020 were not analyzed.

Findings - In the analysis, it is concluded that notifications related to football clubs provide extremely high returns from stocks, and the market is not effective.

Conclusions - As a result of the notifications of important transfers to PDP, all news channels and newspapers give an important place to this notification. As a result of this situation, people can buy the stocks of their existing teams by not acting rationally and with the awareness of fans. Based on this, it is understood that the transfer news is effective for Turkish football clubs. Keywords: Football clubs, Stock returns, Public disclosure platform, Event study, News. JEL Codes: G14, G30

ÖZ

Amaç - Bu araștırmanın amacı Beşiktaş, Galatasaray, Fenerbahçe ve Trabzonspor kulüplerinin Kamuyu Aydınlatma Platformu (KAP) bildirimlerinin hisse senedi getirilerine etkisini incelemektir.

Yöntem -Araştırmada 2009-2010/2019-2020 sezonu verileri kullanılmıştır ve hisse senedi getirilerindeki değişiklikler belirlenmiştir. Ancak COVID-19 salgını nedeniyle 2020 sezonu verileri analize dâhil edilmemiştir.

Bulgular - Analizlerde futbol kulüpleri ile ilgili bildirimlerin hisse senetlerinde yüksek getiriye sebep olduğu ve piyasanın etkin olmadığı sonucuna ulașılmıștır.

Sonuç - KAP’a yapılan önemli transfer bildirimleri haber kanalları ve gazetelerde önemli yer tutmaktadır. Bu durum çerçevesinde kişiler rasyonel davranmayarak taraftarlık bilinciyle kulüplerin hisse senetlerini satın almaktadırlar. Bu açıdan transfer haberlerinin Türk futbol kulüpleri için etkili olduğu sonucuna ulaşılmıștır.

Anahtar Kelimeler: Futbol kulüpleri, Hisse senedi getirileri, Kamuyu aydınlatma platformu, Olay çalıșması, Haberler.

JEL Kodları: G14, G30 


\section{INTRODUCTION}

Football, the world's most popular sport, produces its own ecosystem with its economic, social and social activities (Ratten, 2020). With the emergence of Sheffield, the world's first club in 1857, football has rapidly increased its popularity since the end of the 19th century and has become a sport in which 250 million people actively play and 1.4 billion people are interested in (Giulianotti and Robertson, 2004; Müge, 2020)

However, today, football cannot be defined only as a sport when evaluated with millions of dollars in broadcast revenues, sponsorship agreements, football player contracts, matchday revenues and its relationship with other business lines (Saatçioğlu and Çakmak, 2019). According to the 2020 report of Deloitte, one of the world's leading auditing companies, the European football market revenue increased by $2 \%$ in the 2018/2019 season compared to the 2017/2018 season, reaching 28.9 billion Euros. (Deloitte, 2020). In this respect, the football industry emerges as a sector that needs to be researched financially.

The applicability of corporate governance in the football industry has brought up the issue, with the gradual growth of the football market and its becoming a sector (Farquhar et al., 2005). The purpose of corporate governance practices is to improve the management models of clubs, to add value to clubs and football, to professionalize club management and to increase shareholders' earnings (Rezende et al., 2010). The understanding of corporate governance is built on four basic principles in the international arena: fairness, responsibility, transparency and accountability. It creates value for shareholders by working in harmony with the four basic principles of performance measurement and performance improvement (Pamukçu, 2011). Capital Markets Board of Turkey $(\mathrm{CMB})$ is a regulatory institution in the capital market that published the corporate governance principles in 2003 to improve its corporate governance practices. The principles were reviewed and finalized in 2005 (Yenice and Dölen, 2013).

CMB corporate governance principles are grouped under four headings: public disclosure, transparency, stakeholders and the board of directors (CMB, 2005). Among the principles, the principles of public disclosure and transparency aim to provide the shareholders and stakeholders with timely, accurate, complete, understandable, analytical, easily accessible information at low cost (CMB, 2005). Efficient operation of the public disclosure system is extremely important in terms of efficient functioning of capital markets and fulfilment of the functions expected from it. Thus, the problem of asymmetric information will be eliminated and the rights of investors and stakeholders will be protected (Çörtük and Erten, 2016).

In Turkey, public enlightenment takes place by means of the PDP. It is an electronic system where the notifications required to be disclosed to the public in accordance with the capital market legislation are transmitted with electronic signature and announced to the public. It is obligatory to send all kinds of information and documents to be disclosed to the public within the scope of the "Public Disclosure Platform Communiqué" of the CMB (www.kap.org.tr). In this context, Turkish football clubs whose stocks are traded on the stock exchange; Beşiktaş, Fenerbahçe, Galatasaray and Trabzonspor also report news and developments that concern investors to the PDP. Clubs inform their investors and shareholders by informing the PDP of football player meetings, transfer and sponsorship agreements.

There are many studies that examine the factors that affect the financial performance of football clubs (Hoffmann et al., 2002; Pinnuck and Potter, 2006; Johnston, 2009; Kudo et al., 2015; Freitas et al., 2017; Eryiğit and Eryiğit, 2019). Especially in the literature, studies on the stock return of the match results are frequently discussed. However, there are very few studies in the national and international literature examining the effect of football clubs' player transfers and sponsorship agreements announcements on stock returns. However, unlike other countries, a large portion of the people living in Turkey, Besiktas, Galatasaray, Fenerbahce and Trabzonspor is in favor of the club. Therefore, the results of studies in other countries, the results of the football club located in Turkey may be different from each other. In addition, the results to be obtained in this study can have an impact on the investment decisions of investors trading short-term stocks. In this context, this study will contribute to national and international literature.

In this study, the effect of PDP declarations of Beşiktaş, Fenerbahçe, Galatasaray and Trabzonspor clubs whose stocks are traded in Borsa Istanbul (BIST) on stock returns was investigated. In the research, stock returns were analyzed five days before and five days after PDP notification with the case study method, and the results were explained within the framework of the efficient market hypothesis. The contribution of the obtained results to the efficient market hypothesis reveals the theoretical contribution of the research, while the effect of PDP notifications on financial performance reveals the managerial contribution. 


\section{LITERATURE REVIEW AND HYPOTHESES DEVELOPMENT}

After Kendall (1953) demonstrated that stocks act completely randomly and do not follow a path depending on the price movements in the past, Fama (1965) defined the market where the company information is open to all investors and everyone wants to maximize their profits. Accordingly, as new information comes to the markets regarding firms, this information is reflected on stocks and stock prices come to balance again. The efficient market hypothesis is examined in three forms. These are weak form, semi-strong form, and strong form. Information about the previous price of the stock in weak form is reflected in the stock. In the semi-strong form, the information obtained by the society is reflected in the stock price, while in the strong form, all the information about the firm is reflected in the stock price.

However, Ross et al. (2019) stated that no investor can achieve an abnormal return in an efficient market. In this context, the notifications made by football clubs to PDP and the effect of these notifications on stock prices can be explained within the framework of the efficient market hypothesis. There is a large literature investigating the factors affecting the stock price. When the relevant literature is examined, it is seen that the factors affecting the stock price are mostly tried to be explained by market and accountingbased financial performance indicators such as dividend distribution, book value, earnings per share or financial leverage, or macroeconomic variables (Uddin, 2009; Sanju et al., 2011). ; Eita, 2012; Sharif et al., 2015).

In Turkey, it is observed that research examining the stock performance of football clubs focuses on the relationship between stock performance and sporting success (Devecioğlu, 2004; Aygören et al., 2008; White et al., 2010; Uludag and Sigall, 2013; Zeren and Gümüş., 2013) . On the other hand, there are a limited number of studies examining the effect of information disclosed to the public by companies whose stocks are traded on the stock performance. In this context, the research will fill the gap in the literature by analyzing the effect of the statements made by football clubs, whose shares are traded on the stock exchange, to the PDP on stock performance.

Eryiğit and Eryiğit (2019) separated the sponsors as foreign sponsors and domestic sponsors in their research using the t-test and concluded that this distinction has an effect on the stock performance of clubs. In the study, it was determined that clubs with foreign sponsors have higher stock returns than clubs with domestic sponsors. Although there are few studies investigating the direct effects of player interviews, transfer notifications and sponsorship agreement announcements made by football clubs to the PDP on stock returns, there are studies examining the effect of player transfers and wages paid to players on stock returns (Wiseman and Sangit, 2003; Szymanski and Smith, 2010, Gerard, 2010; Dimitropoulos and Limperopoulos, 2014). Although the research does not directly reveal the relationship between public disclosures and stock returns, it is important in revealing the mediating effect of player transfers on stock returns. While the studies reveal that player transfers and high wages increase the sportive performance and the increased sportive performance has a positive effect on the stock prices of the clubs (Temizel, et al., 2013), there are also studies that reveal that the high transfer fees paid do not always bring sports success (Çatı et al. ., 2017). Babacan and Özer (2014) stated that mandatory and voluntary disclosures made to the public also have an impact on stock prices.

In the study, it is noted that the announcements of the agreements to be signed with the new players are legally mandated, and it is concluded that these statements have affected football clubs' performance of the stock. Healy et al. (1999) stated that voluntary disclosures provide transparency and eliminate the problem of asymmetric information, and there is a positive relationship between the voluntary disclosure level and stock price. In this context, research reveals that public disclosures affect stock prices by eliminating the problem of asymmetric information (Akerlof, 1970; Diamond and Verrecchia, 1991; Healy and Palepu, 1993).

This research investigates the impact of PDP notifications on stock prices of four major sports clubs operating in Borsa Istanbul by using event analysis method. Accordingly, we develop the following hypotheses in accordance with the literature.

H1: Public disclosures of clubs are effective on stock prices.

H1a: Sponsorship announcements have a positive effect on stock prices.

H1b: Player transfer meeting announcements have a positive effect on stock prices. 
H1c: Player transfer announcements have a positive effect on stock prices.

Research results provide theoretical and managerial contributions. The contribution of the obtained results to the efficient market hypothesis reveals the theoretical contribution of the research, while the effect of PDP notifications on financial performance reveals the managerial contribution.

\section{METHODOLOGY}

The main purpose of this research is to examine the effect of PDP notifications of football clubs on stock returns. In the study, data from Beşiktaş, Galatasaray, Fenerbahçe and Trabzonspor clubs were used. In the study, the transfer meeting statements of football clubs, statements regarding the positive results of the transfer negotiations and the dates of the sponsorship agreement were evaluated as notification dates. The data of 2009-2010 and 2019-2020 seasons were used and the changes in stock returns before and after the event (notification date) were determined. However, due to the COVID-19 outbreak, the data in 2020 were not included in the analysis. In the study, the stock prices 5 days before and 5 days after the event / notification took place were compared with the paired t-test. In the study parametric methods were used due to the normal distribution of data.

\section{FINDINGS}

In this part of the study, empirical findings about the effect of PDP declarations on stock returns are presented. The data of four football clubs were analyzed separately.

Table 1. The Effect of Player Transfer Agreement Notifications on Stocks (BJK)

\begin{tabular}{lcccccc}
\hline & & $\mathbf{N}$ & Mean & Std. Deviation & T & Sig. (2-tailed) \\
\hline Stock Price & Before Notification & 145 & 3,9363 &, 89780 & & \multirow{2}{*}{, 298} \\
\cline { 2 - 5 } & After Notification & 145 & 3,9683 &, 93572 & & \\
\hline
\end{tabular}

In Table 1, for Beşiktaş, the effect of player transfer agreement notifications on stocks is analyzed by paired t-test. Between January 1, 2017 and December 31, 2019, Beşiktaş has reported 29 player transfer agreements. In the analysis, the stock prices 5 days before and 5 days after the player transfer agreement notification are compared. As a result of the analysis, it was observed that Beşiktaş's stock prices increased by $0.80 \%$ after the notification of the player transfer agreement.

Table 2. The Effect of Player Transfer Agreement Notifications on Stocks (Fenerbahçe)

\begin{tabular}{|c|c|c|c|c|c|c|}
\hline & & $\mathbf{N}$ & Mean & Std. Deviation & $\mathbf{T}$ & Sig. (2-tailed) \\
\hline \multirow[t]{2}{*}{ Stock Price } & Before Notification & 25 & 11,7991 & 4,25946 & \multirow{2}{*}{,- 185} & \multirow{2}{*}{, 854} \\
\hline & After Notification & 25 & 12,0149 & 3,98519 & & \\
\hline
\end{tabular}

In Table 2, the effect of player transfer agreement notifications on stocks in terms of Fenerbahçe was examined by paired t-test. Between January 1, 2017 and December 31, 2019, Fenerbahçe reported 5 player transfer agreements. In the analysis, the stock prices 5 days before and 5 days after the player transfer agreement notification are compared. As a result of the analysis, it was observed that Fenerbahçe's stock prices increased by $1.80 \%$ after the player transfer agreement was notified.

Table 3. The Effect of Player Transfer Agreement Notifications on Stocks (Galatasaray)

\begin{tabular}{|c|c|c|c|c|c|c|}
\hline & & $\mathbf{N}$ & Mean & Std. Deviation & $\mathbf{T}$ & Sig. (2-tailed) \\
\hline \multirow[t]{2}{*}{ Stock Price } & Before Notification & 360 & 1,7866 &, 43805 & \multirow{2}{*}{$-1,204$} & \multirow{2}{*}{,209 } \\
\hline & After Notification & 360 & 1,8261 & ,44209 & & \\
\hline
\end{tabular}

In Table 3, the effect of player transfer agreement notifications on stocks for Galatasaray has been examined by paired t-test. Between January 1, 2017 and December 31, 2019, Galatasaray reported 72 player transfer agreements. In the analysis, the stock prices 5 days before and 5 days after the player transfer agreement notification are compared. As a result of the analysis, it was observed that Galatasaray's stock prices increased by $2.16 \%$ after the player transfer agreement was notified. 
Table 4. The Effect of Player Transfer Agreement Notifications on Stocks (Trabzonspor)

\begin{tabular}{ccccccc}
\hline \multirow{2}{*}{ Stock Price } & $\mathbf{N}$ & Mean & Std. Deviation & & T & Sig. (2-tailed) \\
\cline { 2 - 5 } & Before Notification & 335 & 1,7374 &, 81320 & \multirow{2}{*}{, 275} &, 778 \\
\cline { 2 - 6 } & After Notification & 335 & 1,7215 &, 67616 & &, 76 \\
\hline
\end{tabular}

In Table 4, for Trabzonspor, the effect of player transfer agreement notifications on stocks was analyzed by paired t-test. Between January 1, 2017 and December 31, 2019, Trabzonspor reported a player transfer agreement 67 times. In the analysis, the stock prices 5 days before and 5 days after the player transfer agreement notification are compared. As a result of the analysis, it was observed that Trabzonspor lost $0,92 \%$ value in stock prices after the player transfer agreement was notified.

Table 5. The Effect of Transfer Meeting Notifications with Players on Stocks (Beşiktaş)

\begin{tabular}{lcccccc}
\hline & & $\mathbf{N}$ & Mean & Std. Deviation & T & Sig. (2-tailed) \\
\hline \multirow{2}{*}{ Stock Price } & Before Notification & 125 & 4,0795 &, 77463 & & \multirow{2}{*}{, 664} \\
\cline { 2 - 5 } & After Notification & 125 & 4,1231 &, 80915 &,- 435 & \\
\hline
\end{tabular}

In Table 5, the effect of the transfer meeting notifications with the players on the stocks for Beşiktaş was examined with the paired t-test. Beşiktaş reported transfer meetings with the players 25 times between January 1, 2017 and December 31, 2019. In the analysis, 5 days before and 5 days after the transfer call notification with the players, stock prices were compared. As a result of the analysis, it was observed that the stock prices of Beşiktaş increased by 1.05\% after the notification of the transfer meeting with the players.

Table 6. The Effect of Transfer Meeting Notifications with Players on Stocks (Fenerbahçe)

\begin{tabular}{|c|c|c|c|c|c|c|}
\hline & & $\mathbf{N}$ & Mean & Std. Deviation & $\mathbf{T}$ & Sig. (2-tailed) \\
\hline \multirow[t]{2}{*}{ Stock Price } & Before Notification & 10 & 14,2200 & 4,12449 & \multirow{2}{*}{,108 } & \multirow{2}{*}{,915 } \\
\hline & After Notification & 10 & 14,0350 & 3,49164 & & \\
\hline
\end{tabular}

In Table 6, in terms of Fenerbahçe, the effect of the transfer call notifications with the players on the stocks was examined with the paired t-test. Between January 1, 2017 and December 31, 2019, Fenerbahçe reported two transfer meetings with the players. In the analysis, 5 days before and 5 days after the transfer call notification with the players, stock prices were compared. As a result of the analysis, it was observed that Fenerbahçe's stock prices lost $1.32 \%$ after the notification of the transfer meeting with the players.

Table 7. The Effect of Transfer Meeting Notifications with Players on Stocks (Galatasaray)

\begin{tabular}{|c|c|c|c|c|c|c|}
\hline & & $\mathbf{N}$ & Mean & Std. Deviation & $\mathbf{T}$ & Sig. (2-tailed) \\
\hline \multirow[t]{2}{*}{ Stock Price } & Before Notification & 140 & 1,8022 &, 43345 & \multirow{2}{*}{,- 664} & \multirow{2}{*}{, 507} \\
\hline & After Notification & 140 & 1,8368 & ,43713 & & \\
\hline
\end{tabular}

In Table 7, for Galatasaray, the effect of the transfer call notifications with the players on the stocks was examined with the paired t-test. Between January 1, 2017 and December 31, 2019, Galatasaray reported 28 transfer meetings with the players. In the analysis, 5 days before and 5 days after the transfer call notification with the players, stock prices were compared. As a result of the analysis, it was observed that Galatasaray's stock prices increased by $1.88 \%$ after the notification of the transfer meeting with the players.

Table 8. The Effect of Transfer Meeting Notifications with Players on Stocks (Trabzonspor)

\begin{tabular}{|c|c|c|c|c|c|c|}
\hline & & $\mathbf{N}$ & Mean & Std. Deviation & $\mathbf{T}$ & Sig. (2-tailed) \\
\hline \multirow[t]{2}{*}{ Stock Price } & Before Notification & 155 & 1,5041 &, 75052 & \multirow{2}{*}{,- 653} & \multirow{2}{*}{, 514} \\
\hline & After Notification & 155 & 1,5581 & ,70373 & & \\
\hline
\end{tabular}

In Table 8, for Trabzonspor, the effect of the transfer call notifications with the players on the stocks was examined with the paired t-test. Between January 1, 2017 and December 31, 2019, Trabzonspor reported 31 transfer meetings with the players. In the analysis, 5 days before and 5 days after the transfer call notification with the players, stock prices were compared. As a result of the analysis, it was observed that Trabzonspor's stock prices increased by $3.47 \%$ after the notification of the transfer meeting with the players. 
Table 9. Effect of Sponsorship Agreement Notifications on Stocks (Beşiktaş)

\begin{tabular}{lcccccc}
\hline & & $\mathbf{N}$ & Mean & Std. Deviation & T & Sig. (2-tailed) \\
\hline \multirow{2}{*}{ Stock Price } & Before Notification & 55 & 1,9079 & ,62441 & \multirow{2}{*}{, 107} & \multirow{2}{*}{, 915} \\
\cline { 2 - 5 } & After Notification & 55 & 1,8950 &, 63852 & & \\
\hline
\end{tabular}

In Table 9, the effect of the notifications for which a sponsorship agreement has been signed for Beşiktaş, on the stock, was analyzed with the paired t-test. Beşiktaş reported 11 sponsorship agreements between 1 May 2009 and 31 December 2019. In the analysis, 5 days before and 5 days after the sponsorship agreement notification stock prices were compared. As a result of the analysis, it was observed that after the sponsorship agreement was notified, Beşiktaş's stock prices lost $0.68 \%$.

Table 10. The Effect of Sponsorship Agreement Notifications on Stocks (Fenerbahçe)

\begin{tabular}{|c|c|c|c|c|c|c|}
\hline & & $\mathbf{N}$ & Mean & Std. Deviation & $\mathbf{T}$ & Sig. (2-tailed) \\
\hline \multirow[t]{2}{*}{ Stock Price } & Before Notification & 15 & 19,0338 & 3,10089 & \multirow{2}{*}{$-1,127$} & \multirow{2}{*}{,269 } \\
\hline & After Notification & 15 & 20,6090 & 4,43470 & & \\
\hline
\end{tabular}

In Table 10, the effect of the notifications with which a sponsorship agreement has been signed for Fenerbahçe on the stock has been analyzed with the paired t-test. Between May 1, 2009 and December 31, 2019, Fenerbahçe notified that sponsorship agreements were made 3 times. In the analysis, 5 days before and 5 days after the sponsorship agreement notification stock prices were compared. As a result of the analysis, it was observed that Fenerbahçe's stock prices increased by $7.64 \%$ after the sponsorship agreement was declared.

Table 11. The Effect of Sponsorship Agreement Notifications on Stocks (Galatasaray)

\begin{tabular}{|c|c|c|c|c|c|c|}
\hline & & $\mathbf{N}$ & Mean & Std. Deviation & $\mathbf{T}$ & Sig. (2-tailed) \\
\hline \multirow[t]{2}{*}{ Stock Price } & Before Notification & 80 & 2,6312 & 1,76420 & \multirow{2}{*}{,119 } & \multirow{2}{*}{,906 } \\
\hline & After Notification & 80 & 2,5983 & 1,75061 & & \\
\hline
\end{tabular}

In Table 11, the effect of the notifications with which a sponsorship agreement was signed for Galatasaray on the stock was analyzed by paired t-test. Between May 1, 2009 and December 31, 2019, Galatasaray reported 16 sponsorship agreements. In the analysis, 5 days before and 5 days after the sponsorship agreement notification stock prices were compared. As a result of the analysis, it was observed that after the sponsorship agreement was notified, Galatasaray's stock prices lost $1.26 \%$.

Table 12. The Effect of Sponsorship Agreement Notifications on Stocks (Trabzonspor)

\begin{tabular}{|c|c|c|c|c|c|c|}
\hline & & $\mathbf{N}$ & Mean & Std. Deviation & $\mathbf{T}$ & Sig. (2-tailed) \\
\hline \multirow[t]{2}{*}{ Stock Price } & Before Notification & 100 & 2,0448 &, 87414 & \multirow{2}{*}{025} & \multirow{2}{*}{,980 } \\
\hline & After Notification & 100 & 2,0417 & 87229 & & \\
\hline
\end{tabular}

In Table 12, the effect of the notifications for which Trabzonspor has signed a sponsorship agreement on the stock has been analyzed by paired t-test. Trabzonspor reported 20 sponsorship agreements between 1 May 2009 and 31 December 2019. In the analysis, 5 days before and 5 days after the sponsorship agreement notification stock prices were compared. As a result of the analysis, it was observed that Trabzonspor lost $0.15 \%$ in stock prices after the sponsorship agreement was declared.

Table 13. Comparison of Teams

\begin{tabular}{lcccccc}
\hline Teams & $\begin{array}{c}\text { The Number } \\
\text { of Player } \\
\text { Transfer } \\
\text { Agreement } \\
\text { Notification }\end{array}$ & $\begin{array}{c}\text { Changes in } \\
\text { Share Prices }\end{array}$ & $\begin{array}{c}\text { The Number of } \\
\text { Transfer } \\
\text { Meeting } \\
\text { Notification } \\
\text { with Players }\end{array}$ & $\begin{array}{c}\text { Changes in } \\
\text { Share Prices }\end{array}$ & $\begin{array}{c}\text { The Number } \\
\text { of } \\
\text { Sponsorship } \\
\text { Agreement } \\
\text { Notification }\end{array}$ & $\begin{array}{c}\text { Changes in } \\
\text { Share Prices }\end{array}$ \\
\hline BJK & 29 & $\% 0,80$ & 25 & $+\% 1,05$ & 11 & $-\% 0,68$ \\
\hline FB & 5 & $+\% 1,80$ & 2 & $-\% 1,32$ & 3 & $+\% 07,64$ \\
\hline GS & 72 & $+\% 2,16$ & 28 & $+\% 1,88$ & 16 & $-\% 1,26$ \\
\hline TS & 67 & $-\% 0,92$ & 31 & $+\% 3,47$ & 20 & $\% 0,15$ \\
\hline
\end{tabular}


Teams in Table 13; Player transfer agreement, transfer meeting with players and sponsorship agreement notifications were compared. Among the teams, Galatasaray (GS) reported the most player transfer agreement (67 times). On the other hand, Trabzonspor (TS) notified transfer meeting with the players 31 times. Trabzonspor S.K is the club with the highest number of sponsorship agreement declarations. Compared to before and after the notification of the player transfer agreement, the biggest change in stock prices was experienced in Galatasaray S.K shares with an increase of $2.16 \%$. Before and after the transfer call notification, the biggest change in stock price Trabzonspor S.K. Fenerbahçe S.K was the club that experienced the biggest change in its shares compared to before and after the notification of the sponsorship agreement. One of the important findings is that Fenerbahçe S.K. is the club that has made the least sponsorship agreement notifications, but has the biggest change in stock prices in this category.

\section{CONCLUSION}

In order for capital markets to function effectively and fulfil the functions expected of them, they must continue their activities within the framework of good corporate governance practices. Accordingly, capital markets are expected to act within the principles of fairness, transparency, responsibility and accountability. In this respect, capital markets and businesses operating in these markets are required to inform their investors about their activities as required by these principles. Enterprises operating in capital markets inform their stakeholders, especially investors, through public disclosure systems. Thus, as a requirement of the principle of transparency and good corporate governance, notifications made through public disclosure systems minimize the asymmetric information problem in the markets. Minimizing the asymmetric information problem will ensure the protection of the rights and interests of business stakeholders, especially investors, and will provide confidence in the capital markets and contribute to their efficient operation. In Turkey, the exchange of business and public duties of public disclosure operating in PDP carries out through. There are many researches on the returns or stock performance of companies operating in the world's stock markets and in BIST.

In the study, the effects of the notifications made by the four major sports clubs whose stocks are traded in BIST on the stock returns were examined. The notifications made to the PDP in the study were handled from three angles. These are transfer negotiations, transfer agreements and sponsorship deals. According to the results obtained from the analysis, the number of notifications made by the teams' subject to examination to the PDP under three headings is quite different. The least PDP statement in all three notification types is made by Fenerbahçe S.K. On the other hand, the biggest change in stock returns during the research period was related to the sponsorship agreement notification, and Fenerbahçe S.K. shares have changed by $7.64 \%$. According to the results of the research, it was concluded that the stock prices and their returns after the announcement date changed significantly compared to the pre-release date.

In an efficient market, stock prices reflect all the information. In this context, even if investors do not have enough information about stocks, they do not act more badly than investors who have more information than themselves. However, the results obtained show that the market is not efficient in semi-strong form. Disclosures made by clubs are monitored and evaluated by investors. In this context, full, timely, complete and understandable disclosures made to the public can improve the financial performance of clubs by increasing efficiency in corporate governance. The research results support the results of Allouche and Soulez (2008), Babacan and Özer (2014), Kudo et al. (2015). Accordingly, stocks react to the mandatory and voluntary statements shared by the clubs with the public (Waymire, 1984; Dedman et al., 2008; Johnston, 2010; Eryiğit and Eryiğit, 2019).

In Turkey, football is an important part of society and are followed by a very large section of people of the society, and the vast majority of people are the fans of Besiktas, Galatasaray, Fenerbahce and Trabzonspor. Compared to other sports branches, football is more present in newspapers and social media, and match results or transfers can be on the agenda. As a result of the notifications of important transfers to PDP, all news channels and newspapers give an important place to this notification. As a result of this situation, people can buy the stocks of their existing teams by not acting rationally and with the awareness of fans. Based on this, it is understood that the transfer news is effective for Turkish football clubs.

Findings obtained in this study can be a guide for investors making short term purchases and sales. However, in order to fully understand the effect of transfer and sponsorship agreements on stocks, the need for supportive studies comes to the fore. 
The study has a number of limitations. The first constraint is that the research includes four teams. Apart from this, the research has been carried out in Turkey and has been used in analysing data between the years 2009-2019. For this reason, the results do not allow an overall comparison between countries. Investigating the reasons for the differences in stock returns in future studies may contribute to the literature. In addition, by making distinctions as foreign-domestic transfer or domestic-foreign sponsorship, the effect of this situation on stock returns can be investigated. Apart from this, the re-evaluation of the transfer agreements by making distinctions according to the end of season and mid-season or transfer size will also contribute to the literature.

Ethics Statement: The research is not based on experiment therefore there is no need for ethics committee approval. In case of detection of a contrary situation, the Journal of Social Economic Research has no responsibility and all responsibility belongs to the authors of the study.

Author Contributions Statement: 1 st author's contribution rate is $40 \%$, 2nd author's contribution rate is $30 \%$, 3 rd author's contribution rate is $30 \%$.

Conflict of Interest: The authors declare that there is no conflict of interest.

\section{REFERENCES}

Akerlof, G. (1970). The market for lemons: quality uncertainty and the market mechanism. Quarterly Journal of Economics, 84, 488-500.

Aygören, H., Uyar, S., Sarıtaş, H. (2008). Are investors influenced by the results of football matches? An empirical investigation in Istanbul stock Exchange. Hacettepe University Journal of Economics and Administrative Sciences, 26 (1), 121-137.

Babacan, B., Özer, G. (2014). Voluntary and mandatory transfer disclosures of football teams and behaviour of stock returns: An event study. International Review of Economics and Management, 2(1), 19-35.

Beyaz, Z., Bakırtaş, I. (2010). The effect of the football clubs performance on the stock returns. International Journal of Sport Research, 2 (2).

Çatı, K., Eş, A., Özevin, O. (2017). Sportive and financial performance analysis of football team with entropi and topsis methods: An application on major Europe's 5 leagues and Turkey League. Int. Journal of Management Economics and Business, 13(1), 199-222.

Çörtük, O., Erten, M. (2016). The efficiency of public disclosure for capital markets in Turkey. Istanbul University Journal of the School of Business, 45(1), 65-77.

Deloitte. (2020). Annual Review of Football Finance, Available at: https://www2.deloitte.com/uk/en/pages/sports-business-group/articles/annual-review-of-footballfinance.html (02.11.2020).

Devecioğlu, S. (2004). The relation between sports success and market price of sport clubs supply to public. Spormetre The Journal of Physical Education and Sport Sciences, 2 (1), 11-18.

Diamond, D.W., Verrecchia, R.E. (1991). Disclosure, liquidity, and the cost of capital. The Journal of Finance, Avaliable at: https://doi.org/10.1111/j.1540-6261.1991.tb04620.x (05.11.2020)

Dimitropoulos, P.E., Limperopoulos, V. (2014). Player contracts, athletic and financial performance of the Greek football clubs. Global Business and Economics Review, 16(2), 123-141.

Eiata, J.H. (2012). Modelling macroeconomic determinants of stock market prices: Evidence from Namibia. The Journal of Applied Business Research, 28(5), 871-884.

Eryiğit, C., Eryiğit, M. (2019). The effect of sponsorship announcements on stock returns of sponsees. International Journal of Sport Finance, 14(3), 173-190.

Farquhar, S., Machold, S., Ahmed, P.K. (2005). Governance and football: An examination of the relevance of corporate governance regulations for the sports sector. International Journal of Business Governance and Ethics, 1(4), 329-349. 
Freitas, M.M., Farias, R.A.S., Flach, L. (2017). Efficiency determinants in Brazilian football clubs. Brazilian Business Review, 1-23.

Gerrard, B. (2010). Analyzing sporting efficiency using standardized win cost: Evidence from the FA premier league, 1995-2007. International Journal of Sports Science and Coaching, 5(1), 13-35.

Giulianotti, R., Robertson, R. (2004). The globalization of football: A study in the glocalization of the serious life. The British Journal of Sociology, 55(4), 545-568.

Healy, M.P., Palepu, K.G. (1993). The effects of firms' financial disclosure strategies on stock prices. American Accounting Association Accounting Horizons, 7 (1), 1-11.

Healy, M.P, Hutton, A.P., Palepu, K.G. (1999). Stock performance and intermediation changes surrounding sustained increases in disclosure. Contemporary Accounting Research, 16(3), 485-520.

Hoffmann, R., Ging, L.C., Ramasamy, B. (2002). The socio-economic determinants of international soccer performance. Journal of Applied Economics, 5(2), 253-272, DOI: 10.1080/15140326.2002.12040579.

Johnstone, M.A. (2010). The impact of sponsorship announcements on shareholder wealth in Australia. Asia Pacific Journal of Marketing and Logistics, 22(2), 156-178.

Kudo, M., Ko, Y.J., Walker, M., Connaughton, D.P. (2015). The influence of title sponsorships in sports events on stock price returns. International Journal of Sports Marketing and Sponsorship, Research Paper.

Müge, D. (2020). Industrial football and the use of technology in football. TRT Academy, 5(9), 356-375.

Pamukçu, F. (2011). The importance of corporate governance in public disclosure and transparency by financial reporting. The Journal of Accounting and Finance, 50, 133-148.

Pinnuck, M., Potter, B. (2006). Impact of on-field football success on the off-field financial performance of AFL football clubs. Accounting and Finance, 46, 499-517.

Ratten, V. (2020), Football ecosystems and innovation, Ratten, V. (Ed.) Sport Startups: New Advances in Entrepreneurship, Emerald Publishing Limited, 71-87. https://doi.org/10.1108/978-1-78973-081-420201006

Rezende, A.J., Dalmacio, F.Z., Facure, C.E.F. (2010). Practice of corporate governance in football clubs, International Journal of Economics and Accounting, 1(4), 410-447.

Saatçioğlu, C., Çakmak, U.D. (2019). Football economy in Europe and Turkey: A comparative study. The Sakarya Journal of Economics, 8(4), 331-350.

Sanju, P. S., Ramachandran, M., Nirmala, P.S. (2011). Determinants of share prices in India. Journal of Emerging Trends in Economics and Management Sciences, 2(2), 124-130.

Sharif, T., Purohit, H., Pillai, R. (2015). Analysis of factors affecting share prices: The case of Bahrain stock Exchange. International Journal of Economics and Finance, 7(3), 207-216.

CMB (Capital Markets Board) (2005). Corporate Governance Principles, Ankara, Turkey.

Szymanski, S., Smith, R. (2010). The English football industry: Profit, performance and industrial structure. Football Economics and Policy, Palgrave Macmillan, USA.

Temizel, F., Özata, E., Esen, E. (2013). The analysis of the relationship between spotive performances of the football teams and their stock returns: The Turkish case. TISK Akademi, 8(15), 178-197.

Uddin, M. B. (2009). Determinants of market price of stock: A Study on bank leasing and insurance companies of Bangladesh. Journal of Modern Accounting and Auditing, S5(7): 1-7.

Uludă̆, B., Sigalı, S. (2013). Impact of sporting performance on financial performance: An analysis of 4 big soccer clubs in Turkey. Ege Academic Review, 16(4), 575-585.

Wiseman, F., Sangit, C. (2003). Team payroll and team performance in major league baseball: 1985-2002. Economics Bulletin, 1(2), 1-10.

Yenice, S., Dölen, T. (2013). The effect of harmonization to the principles of corporate governance on the firm value of publicly-traded firm in ISE. Int. Journal of Management Economics and Business, 9(19), 199-214. 
Zeren, F., Gümüş, F. B. (2013). An application on performances of the Turkish and foreign football teams in their stock markets. Cankern Karatekin University Journal of the Faculty of Economics and Administrative Sciences, 3 (2), 34-54.

https://www.kap.org.tr/tr/menu-icerik/KAP-Hakkinda/Genel-Bilgi, Çevrimiçi (20.11.2020). 